\title{
Chemical and morphological characterization of Allium tuncelianum (Amaryllidaceae) and its antioxidant and anticholinesterase potentials
}

\author{
Songul KARAKAYA ${ }^{1, *}$, Gulnur EKSI ${ }^{2}$, Mehmet KOCA ${ }^{3}$, Betul DEMIRCI ${ }^{4}$, \\ Haluk Caglar KAYMAK ${ }^{5}$, Mehmet Emin KAPLAN ${ }^{6} \&$ Ozkan AKSAKAL $^{7}$ \\ ${ }^{1,6}$ Department of Pharmacognosy, Faculty of Pharmacy, Ataturk University, Erzurum, Turkey. \\ ${ }^{2}$ Department of Pharmaceutical Botany, Faculty of Pharmacy, Ankara University, Ankara, Turkey. \\ ${ }^{3}$ Department of Pharmaceutical Chemistry, Faculty of Pharmacy, Ataturk University, Erzurum, Turkey. \\ ${ }^{4}$ Department of Pharmacognosy, Faculty of Pharmacy, Anadolu University, Eskisehir, Turkey. \\ ${ }^{5}$ Department of Horticulture, Faculty of Agriculture Ataturk University, Erzurum, Turkey. \\ ${ }^{7}$ Department of Biology, Faculty of Science, Ataturk University, Erzurum, Turkey. \\ "Corresponding author: ecz-songul@hotmail.com, https://orcid.org/0000-0002-3268-721X \\ ${ }^{2}$ gulnur_eksi@yahoo.com, https://orcid.org/0000-0002-6869-8703 \\ ${ }^{3}$ kocamehmet@atauni.edu.tr, https://orcid.org/0000-0002-1517-5925 \\ 흘uldemirci@gmail.com, https://orcid.org/0000-0003-2343-746X \\ ${ }^{5}$ hckaymak@atauni.edu.tr, https://orcid.org/0000-0002-0836-7654 \\ ${ }^{6}$ ecz.eminkaplan@gmail.com, https://orcid.org/0000-0001-6833-4451 \\ 7 ozkanaksakal@atauni.edu.tr,, https://orcid.org/0000-0003-0760-7502
}

\begin{abstract}
Alzheimer's disease is the main reason for dementia, which increases with age. Cholinesterase inhibition and antioxidant potentials of extracts and essential oils from bulbs of A. tuncelianum (Kollmann) Özhatay \& al., an endemic species to Tunceli (easthern Turkey), were evaluated. The fraction extracted of ethyl acetate had the highest phenolics level, 1,1-diphenyl-2-picrylhydrazyl, and thiobarbituric acid antioxidant capacity. Also, the ethyl acetate fraction presented the highest acetylcholinesterase $(15.98 \pm 2.76 \%)$, and butyrylcholinesterase inhibition $(47.33 \pm 3.27 \%)$. Diallyl disulfide $(49.8 \%)$, diallyl trisulfide $(27.9 \%)$ and allyl methyl trisulfide $(6.9 \%)$ were found to be the major components of essential oil. This paper shows that the ethyl acetate fraction of A. tuncelianum could be a potent source of antioxidant and anticholinesterase components.
\end{abstract}

Keywords. Allium tuncelianum, anticholinesterase, endemic, essential oil, morphology.
Resumen. La enfermedad de Alzheimer es la causa principal de la demencia, cuya aparición aumenta según la edad. Se evaluaron la inhibición de la colinesterasa y el potencial antioxidante de los extractos y los aceites esenciales de los bulbos de A. tuncelianum (Kollmann) Özhatay \& al., una especie endémica de Tunceli (este de Turquía). La fracción extraida de acetato de etilo presentó los niveles más altos de fenoles, 1,1-difenil2-picrilhidrazilo y capacidad antioxidante, ácido tiobarbitúrico. Asimismo, la fracción de etil acetato presentó la mayor capacidad de inhibición de acetilcolinesterasa $(15.98 \pm 2.76 \%)$ y butirilcolinesterasa $(47.33 \pm 3.27 \%)$. El disulfuro de dialilo (49.8\%), el trisulfuro de dialilo (27.9\%) y el trisulfuro de metil alilo $(6.9 \%)$ fueron los componentes principales del aceite esencial. Este artículo muestra que la fracción de etil acetato de $A$. tuncelianum podría ser una fuente potencial novedosa de componentes antioxidantes y anticolinesterasa.

Palabras clave. Aceite esencial, Allium tuncelianum, anticolinesterasa, endémico, morfología.

How to cite this article: Karakaya S., Eksi G., Koca M., Demirci B., Kaymak H.C., Kaplan M.E. \& Aksakal O. 2019. Chemical and morphological characterization of Allium tuncelianum (Amaryllidaceae) and its antioxidant and anticholinesterase potentials. Anales del Jardín Botánico de Madrid 76 (2): e085. https://doi.org/10.3989/ajbm.2523

Title in Spanish: Caracterización química y morfológica de Allium tuncelianum (Amaryllidaceae) y potenciales antioxidantes y anticolinesterasa.

Received: 25-III-2019; accepted: 28-V-2019; published on-line: 28-X-2019; Associate Editors: M.C. Sánchez Mata \& R. Morales.

\section{INTRODUCTION}

Alzheimer's disease (AD) is a neurodegenerative disease characterized by an accumulation of extracellular amyloid-beta peptide $(A \beta)$ and intracellular neurofibrils resulting in a loss of memory. $A \beta$ is the principal constituent of senile plaques that are thought to play a central role in the healing and progression of oligomer and fibril forms of AD. Besides, many studies have shown that oxidative stress and mitochondrial dysfunction might have a substantial role in $\mathrm{AD}$ and that they are suppressed or reduced by using antioxidant agents, suggesting a therapeutic intervention for $\mathrm{AD}$ patients. It is reported that numerous antioxidant components protect the brain from $A \beta$ neurotoxicity (Sgarbossa \& al. 2015). Pharmacological treatments available for $\mathrm{AD}$ occur by relaxation of the symptoms rather than targeting the etiological mechanisms (Ng \& al. 2015). 
Recent investigations have indicated that numerous medicinal herbs are a significant source of antioxidants. Plants include a large number of free radical scavenging molecules, such as alkaloids, tannins, steroids, rotenoids, carotenoids, dietary glutathione, anthocyanins, saponins, terpenoids, and flavonoids. Consequently, medical herbs become popular as a cheap source to discover novel antioxidants (Chand \& al. 2018).

Volatile oils are found to have several pharmacological activities such as hepatoprotective, carminative, antispasmodic, antiviral, and anti-tumor, etc. Nowadays, many volatile oils have been characterized as natural antioxidants and proposed as potential sources for food preservation. Additionally, biologically active natural compounds are of interest to the pharmaceutics industry for the control of human ailments of microbial origin and for the containment of lipid peroxidative damage, which has been implicated in specific pathological diseases such as $\mathrm{AD}$, ischemia-reperfusion injury, cancer, coronary, atherosclerosis, and aging (Mimica \& al. 2004).

The representatives of family Amaryllidaceae J.St.Hil. have been characterized by high phenolics content (Resetár \& al. 2017) and some members of this family have been used in the treatment of AD. Galanthamine is an alkaloid of the Amaryllidaceae that is a competitive selective, long-acting, and reversible acetylcholinesterase inhibitor that maintains the beneficial effects even after treatment (López \& al. 2002).

Garlic has been produced and eaten worldwide and has attracted attention due to its preservative potentials against various diseases. Previous investigations indicated that garlic has numerous biological and pharmacological effective compounds. It is used for medical aims since ancient times, and its usage for cancer treatment dates back to 3,500 years ago (Özkan \& al. 2013).

The genus Allium L. (Amaryllidaceae; cf. APGIII 2009) consists of more than 900 species which naturally grow in the northern hemisphere (Duman \& al. 2017; Ekşi \& al. 2016). According to phylogenetic analyses, A. tuncelianum (Kollmann) Özhatay, B.Mathew \& Şiraneci belongs to the Allium sect. Allium. Fritsch \& Friesen (2002) have proposed that the wild progenitor of garlic species should grow in the district from South Central Asia to the Mediterranean, according to their taxonomic investigations. Mathew (1996) proposed that $A$. tuncelianum might be the wild progenitor of $A$. sativum L. and both share general characters such as the odor of leaves and bulbs.

Because of its similarity to the widespread garlic, it is locally named as 'Ovacik garlic' or 'Tunceli garlic' in the district. Allium tuncelianum generally consists of a single cloved white bulb, unlike garlic, which has bulbs with multiple cloves (Kiralan \& al. 2013). Even though
A. tuncelianum has been considered as a close relative of A. sativum, the precise phylogenetic or genetic relationships are not well known yet.

In this regard, the aim of this paper was to report the cholinesterase inhibitory and antioxidant activity of the methanol, hexane, dichloromethane, ethyl acetate, butanol, and aqueous extracts and essential oils of bulbs of A. tuncelianum. The total phenolic content of extracts and essential oil, as well as the essential oil composition and morphology of A. tuncelianum, were assessed.

\section{MATERIAL AND METHODS}

\section{Plant specimen}

Allium tuncelianum was gathered from Ovac1k, Tunceli province (Eastern Turkey). The voucher specimens have been preserved at the Herbarium of Ataturk University, Faculty of Science under the code ATA-9877.

\section{Extraction}

Dried bulbs of $A$. tuncelianum (50 g) were crushed and macerated with methanol ( 3 times, $8 \mathrm{~h}$ ) in a water-bath not exceeding $35^{\circ} \mathrm{C}(3 \times 100 \mathrm{ml})$ by $200 \mathrm{rpm}$ with using of a mechanical mixer. Combined bulbs extracts were filtered and concentrated by rotary evaporator to dryness, then dissolved in methanol: water $(1: 9)$ and fractionated three times with $150 \mathrm{ml}$ of $\mathrm{n}$-hexane, dichloromethane, ethyl acetate, and n-butanol, respectively.

On the other hand, $50 \mathrm{~g}$ of bulbs of A. tuncelianum were crushed and macerated with $200 \mathrm{ml}$ of distilled water for $8 \mathrm{~h} / 3$ days at 30 to $35^{\circ} \mathrm{C}$. The aqueous extract was filtered, frozen and lyophilized to attain aqueous extracts of bulbs. Amounts of the powdered parts of A. tuncelianum and acquired extracts/fractions are shown in Table 1.

\section{Isolation of the essential oil, GC-FID and GC/MS analyses}

The essential oil isolation, GC-FID, and GC/MS assays were done in accordance with Karakaya \& al. (2016). The crushed part, the percentage of essential oil, and the color of the essential oil are displayed in Table 2.

\section{Determination of total phenolic content}

The total phenolic content of the samples was done in accordance with Karakaya \& al. (2018). The procedure was repeated three times for each sample.

\section{Antioxidant activity}

The quantitative 1,1-diphenyl-2-picrylhydrazyl (DPPH) of the samples was done in Karakaya \& al. (2018). The $\mathrm{IC}_{50}$ values of samples were established by linear regression analysis in triplicate. 
Table 1. Amounts of the powdered parts of A. tuncelianum (Kollmann) Özhatay \& al. and acquired extracts/fractions.

\begin{tabular}{cc}
\hline Extracts/Fractions (g) & Aerial part \\
\hline $\mathrm{MeOH}$ & 14.21 \\
Hexane & 2.08 \\
$\mathrm{CH}_{2} \mathrm{Cl}_{2}$ & 5.11 \\
$\mathrm{EtOAc}$ & 1.03 \\
$\mathrm{BuOH}$ & 3.23 \\
Methanolic residue & 2.96 \\
\hline Lyophilised aqueous extract & 15.44 \\
\hline
\end{tabular}

Table 2. The crushed part, essential oil $\%$ yield $A$. tuncelianum (Kollmann) Özhatay \& al. and color of essential oil (w/v, \%).

\begin{tabular}{ccccc}
\hline Part & Crushed & Yield & Colour & Collection \\
\hline bulbs & $220 \mathrm{~g}$ & 0.0046 & White & 2018 \\
\hline
\end{tabular}

Table 3. Total phenolic contents of the extracts, fractions and essential oil from $A$. tuncelianum (Kollmann) Özhatay $\&$ al. [The data present the mean \pm SD of three independent experiments $(\mathrm{p}<0.05)]$.

\begin{tabular}{cc}
\hline Tested samples & Total phenolic contents $(\mathbf{m g} / \mathbf{g}) \pm$ SD \\
\hline $\mathrm{MeOH}$ & $377.25 \pm 4.78$ \\
Hexane & $67.78 \pm 1.56$ \\
$\mathrm{CH}_{2} \mathrm{Cl}_{2}$ & $434.61 \pm 4.12$ \\
$\mathrm{EtOAc}$ & $666.45 \pm 3.21$ \\
$\mathrm{BuOH}$ & $124.05 \pm 2.44$ \\
Methanolic residue & $338.14 \pm 5.34$ \\
Lyophilised aqueous extract & $567.20 \pm 3.07$ \\
Essential oil & $209.01 \pm 2.13$ \\
\hline
\end{tabular}

\section{Anti-lipid peroxidation activity}

The anti-lipid peroxidation activity of the samples was done according to Karakaya \& al. (2018). The $\mathrm{IC}_{50}$ values were established through linear regression assay.

\section{Evaluation of AChE and BuChE inhibition activities}

The evaluation of $\mathrm{AChE}$ and $\mathrm{BuChE}$ inhibition followed Karakaya \& al. (2018). The procedure was repeated three times for each plate. All data were denoted as mean $\pm \mathrm{SE}$ of three independent tests.

\section{Statistical analysis}

Overall indications are denoted as mean \pm SE and statistically analyzed through ANOVA one-way analysis followed by way of complementary analysis of Bonferroni $(\mathrm{P}<0.05)$, planned to determine statistical significance.

\section{RESULTS}

General morphology

Allium tuncelianum (Kollmann) Özhatay, B.Mathew \& Şiraneci, Kew Bull. 50 (4): 723 (Özhatay \& Mathew 1995). A. macrochetum subsp. tuncelianum Kollmann, Notes Roy. Bot. Gard. Edinburgh 41: 262 (Kollmann \& al. 1983), bason. Tipo: [Turkey] Tunceli, Munzur Da., Aksu Dere above Ovacik, 1800 m a.s.l., 21 Jul. 1957, Davis 31498 leg. (holo-: E!; iso-: K!). Figs. 1 and 2.

Bulb 1.5-5.5 cm in diameter, ovoid; outer tunics thick, membranous, brownish to dirty yellowish-white; inner tunics thin, membranous, white; bulblets 1-2. Scape 50$150 \mathrm{~cm}$. Leaves 4-8, 1-2.5 cm wide, flat, canaliculate, glabrous, shorter than scape. Spathe 10-20 cm, 1-valved, deciduous. Umbel $2-8 \mathrm{~cm}$ in diameter, spherical, dense (100-200 flowers), bracteolate. Perigone 2.5-3.5 mm, campanulate, pale pinkish to white, smooth. Stamens longer than perigone. Capsule 3-4 $\mathrm{mm}$. Chromosome number $(2 n) 16$.

Distribution and habitat.-East Anatolia; rocky areas, calcareous soils; 1000-2200 m a.s.l.

Phenology.-Flowering time from June to August.

\section{Experimental section}

The methanol extracts of bulbs of $A$. tuncelianum were fragmented using solvents with different polarities $\left(\mathrm{C}_{6} \mathrm{H}_{14}\right.$, $\mathrm{CH}_{2} \mathrm{Cl}_{2}, \mathrm{C}_{4} \mathrm{H}_{8} \mathrm{O}_{2}$, and $\left.\mathrm{C}_{4} \mathrm{H}_{10} \mathrm{O}\right)$. Also, the lyophilised aqueous extract of bulbs was obtained. The extracts, fractions and essential oil were assessed for antioxidant and cholinesterase inhibitory activities. Also, the morphological study of $A$. tuncelianum was also evaluated.

The essential oils, extracts, and fractions of bulbs were estimated with regard to antioxidant capacity effect. The data of samples with regard to total phenolics content are displayed in Table 3. The fraction extracted of ethyl acetate (EtOAc) had the highest level of total phenolic $(666.45 \mathrm{mg}$ $\mathrm{GAE} \mathrm{g}^{-1} \mathrm{DW}$ ) however the hexane fraction got the lowest

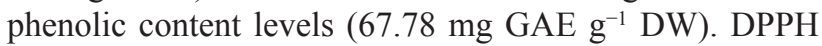
analysis data were presented in Table 4 and the EtOAc fraction got the highest antioxidant activity (17.21 \pm 4.33 $\mu \mathrm{g} / \mathrm{ml})$ and the hexane fraction had the lowest phenolic content $(128.45 \pm 3.56 \mu \mathrm{g} / \mathrm{ml})$. The findings of the analysis of thiobarbituric acid (TBA) were exhibited in Table 5 as $\mathrm{IC}_{50}(\mu \mathrm{g} / \mathrm{ml})$. The EtOAc fraction and lyophilized aqueous extract had the highest antioxidant potential $\left(\mathrm{IC}_{50}=54.67\right.$ and $65.15 \mu \mathrm{g} / \mathrm{ml}$, respectively) in TBA analysis.

Cholinesterase inhibitory activity of samples was revealed via colorimetric Ellman's method (Ellman \& al. 1961), some changes were done following the mentioned method and donepezil was used as a standard (Yerdelen \& Tosun 2015). In vitro cholinesterase inhibitory activity of samples at $100 \mu \mathrm{g} / \mathrm{ml}$ is displayed in Table 6. The EtOAc 


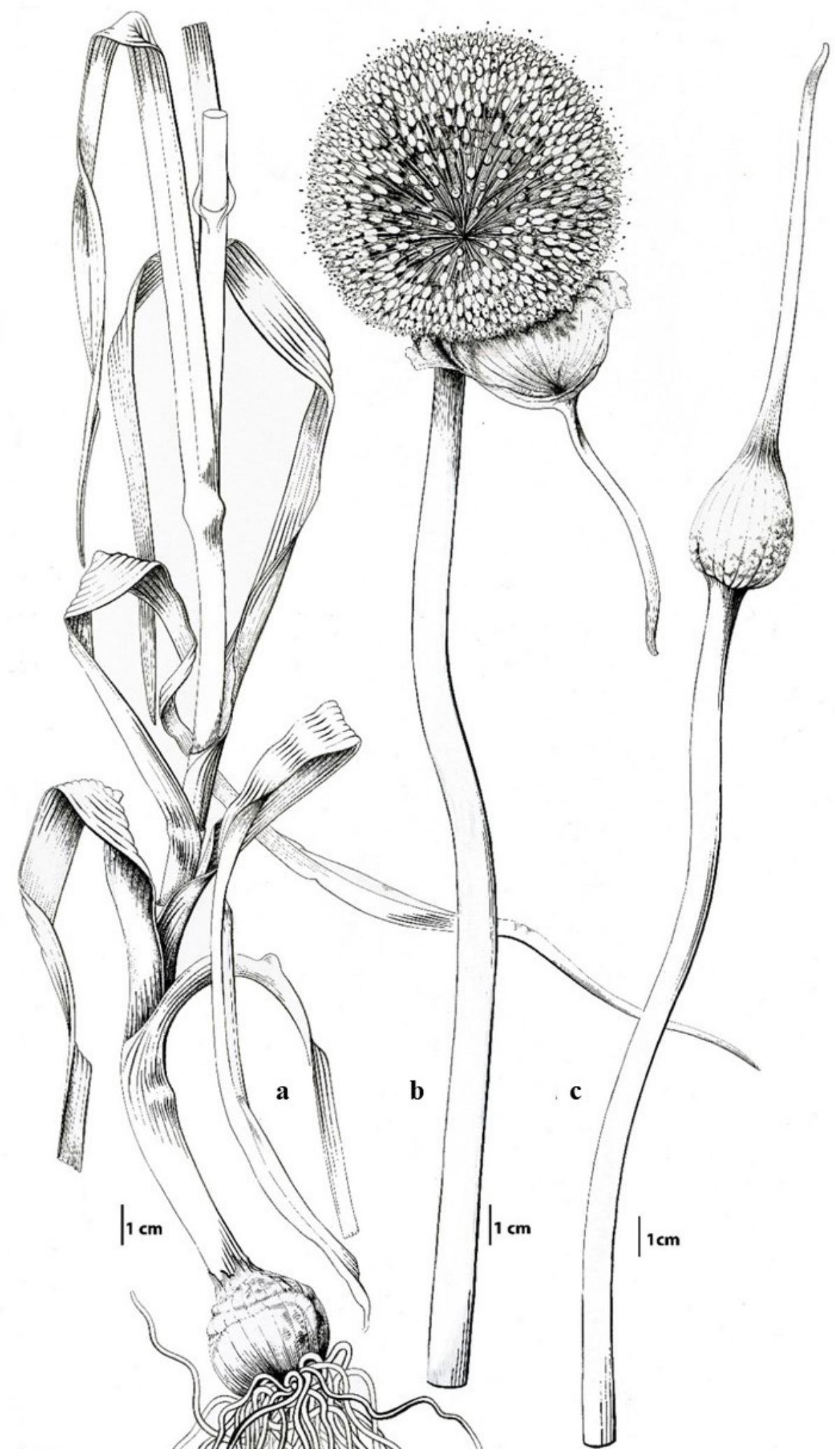

Fig. 1. Allium tuncelianum (Kollmann) Özhatay, B.Mathew \& Şiraneci: a, b, plant during the anthesis; c, plant during the pre-anthesis [AEF 24116; illustrated by Gülnur Ekşi]. 
Table 4. DPPH radical scavenging activity of the the extracts, fractions and essential oil from A. tuncelianum (Kollmann) Özhatay \& al. ( $\mu \mathrm{g} / \mathrm{ml})$ [The data present the mean \pm SD of three independent experiments $(\mathrm{p}<0.05)]$.

\begin{tabular}{cc}
\hline Tested samples & $\mathbf{I C}_{50}$ values $(\boldsymbol{\mu g} / \mathbf{m l}) \pm \mathbf{S D}$ \\
\hline $\mathrm{MeOH}$ & $87.35 \pm 3.42$ \\
Hexane & $105.41 \pm 3.34$ \\
$\mathrm{CH}_{2} \mathrm{Cl}_{2}$ & $31.43 \pm 2.56$ \\
$\mathrm{EtOAc}$ & $17.21 \pm 4.33$ \\
$\mathrm{BuOH}$ & $93.22 \pm 1.66$ \\
\hline Methanolic residue & $128.45 \pm 3.56$ \\
\hline Lyophilised aqueous extract & $52.57 \pm 2.68$ \\
\hline Essential oil & $55.09 \pm 3.22$ \\
\hline Chlorogenic acid & $2.41 \pm 0.58$ \\
\hline Propyl gallate & $0.005 \pm 0.21$ \\
Rutin & $3.05 \pm 0.89$ \\
\hline
\end{tabular}

Table 5. Antioxidant activities of the the the extracts, fractions and essential oil from A. tuncelianum (Kollmann) Özhatay $\&$ al. in TBA test [The data present the mean \pm SD of four independent experiments $(\mathrm{p}<0.05)]$.

\begin{tabular}{cc}
\hline Tested samples & $\mathbf{I C}_{50}$ values $(\boldsymbol{\mu g} / \mathbf{m l}) \pm \mathbf{S D}$ \\
\hline $\mathrm{MeOH}$ & $451.61 \pm 2.98$ \\
$\mathrm{Hexane}$ & $>500$ \\
$\mathrm{CH}_{2} \mathrm{Cl}_{2}$ & $76.67 \pm 3.77$ \\
$\mathrm{EtOAc}$ & $54.67 \pm 4.24$ \\
$\mathrm{BuOH}$ & $166.29 \pm 2.77$ \\
Methanolic residue & $>500$ \\
Lyophilised aqueous extract & $65.15 \pm 1.79$ \\
\hline Essential oil & $89.25 \pm 2.78$ \\
\hline Chlorogenic acid & $12.98 \pm 4.89$ \\
Propyl gallate & $3.44 \pm 2.05$ \\
Rutin & $9.65 \pm 3.09$ \\
\hline
\end{tabular}

and essential oil indicated remarkable inhibition against $\mathrm{BuChE}(47.33 \pm 3.27$ and $28.65 \pm 2.58 \%$, respectively) at $100 \mu \mathrm{g} / \mathrm{ml}$. Also, EtOAc and $\mathrm{CH}_{2} \mathrm{Cl}_{2}$ fractions displayed inhibition against $\mathrm{AChE}(15.98 \pm 2.76$ and $14.12 \pm$ $2.76 \%$, respectively) at $100 \mu \mathrm{g} / \mathrm{ml}$. On the other side, the methanolic residue fraction had no activity against both enzymes. Moreover, $\mathrm{MeOH}$, lyophilized aqueous extracts and hexane, $\mathrm{BuOH}$ fractions had no activity against $\mathrm{AChE}$. EtOAc fraction has been characterized by substantially higher total phenolic content than other samples.

The percentage yield of essential oil of A.tuncelianum and color of essential oil are presented in Table 2. The color of the essential oil was white. A total of five compounds making up $88.9 \%$ of the oil were defined in the bulbs of A. tuncelianum. Diallyl disulfide, diallyl trisulfide and allyl methyl trisulfide were the major components, amounting to $49.8 \%, 27.9$ and $6.9 \%$, respectively. Many of the defined
Table 6. In vitro AChE and BuChE inhibitory activities of samples from A. tuncelianum (Kollmann) Özhatay \& al. at $100 \mu \mathrm{g} / \mathrm{ml}$. [Superscript: a, standard error mean; b, no activity; c, not detected because of turbidity in the wells of microplates. The data present the mean \pm SD of three independent experiments $(\mathrm{p}<0.05)$

\begin{tabular}{|c|c|c|}
\hline Samples & Enyzmes & $\begin{array}{l}\text { Percentile of inhibition } \pm \text { S.E. } \mathrm{M}^{\mathrm{a}} \\
\text { against } \mathrm{AChE} \text { and } \mathrm{BuChE}\end{array}$ \\
\hline \multirow{2}{*}{$\mathrm{MeOH}$} & $\mathrm{AChE}$ & $-^{\mathrm{b}}$ \\
\hline & $\mathrm{BuChE}$ & $9.68 \pm 1.67$ \\
\hline \multirow{2}{*}{ Hexane } & $\mathrm{AChE}$ & $\mathrm{ND}^{\mathrm{c}}$ \\
\hline & $\mathrm{BuChE}$ & $2.56 \pm 2.55$ \\
\hline \multirow{2}{*}{$\mathrm{CH}_{2} \mathrm{Cl}_{2}$} & $\mathrm{AChE}$ & $14.12 \pm 2.76$ \\
\hline & $\mathrm{BuChE}$ & $23.56 \pm 2.65$ \\
\hline \multirow{2}{*}{ EtOAc } & $\mathrm{AChE}$ & $15.98 \pm 2.76$ \\
\hline & $\mathrm{BuChE}$ & $47.33 \pm 3.27$ \\
\hline \multirow{2}{*}{$\mathrm{BuOH}$} & $\mathrm{AChE}$ & $-\mathrm{b}$ \\
\hline & $\mathrm{BuChE}$ & $3.98 \pm 2.56$ \\
\hline \multirow{2}{*}{$\begin{array}{l}\text { Methanolic } \\
\text { residue }\end{array}$} & $\mathrm{AChE}$ & $-{ }^{b}$ \\
\hline & $\mathrm{BuChE}$ & $-\mathrm{b}$ \\
\hline \multirow{2}{*}{$\begin{array}{c}\text { Lyophilised } \\
\text { aqueous extract }\end{array}$} & $\mathrm{AChE}$ & $\mathrm{ND}^{\mathrm{c}}$ \\
\hline & $\mathrm{BuChE}$ & $13.58 \pm 1.93$ \\
\hline \multirow{2}{*}{ Essential oils } & $\mathrm{AChE}$ & $7.59 \pm 2.90$ \\
\hline & $\mathrm{BuChE}$ & $28.65 \pm 2.58$ \\
\hline \multirow{2}{*}{ Donepezil } & AChE & $82.45 \pm 2.64$ \\
\hline & $\mathrm{BuChE}$ & $90.33 \pm 4.16$ \\
\hline
\end{tabular}

Table 7. The essential oil composition of A tuncelianum (Kollmann) Özhatay \& al. RRI Relative retention indices calculated against n-alkanes. \% calculated from FID data.

\begin{tabular}{ccc}
\hline RRI & Compound & \% \\
\hline 1292 & Allyl methyl disulfide & 1.9 \\
1438 & Allyl propenyl disulfide & 2.4 \\
1492 & Diallyl disulfide & 49.8 \\
1607 & Allyl methyl trisulfide & 6.9 \\
1811 & Diallyl trisulfide & 27.9 \\
& Total & 88.9 \\
\hline
\end{tabular}

compounds were sulphur compounds. The compositions of essential oil are presented in Table 7.

\section{DISCUSSION}

Previously, it was observed that $\mathrm{MeOH}$ extract of the bulb of A. tuncelianum showed high antioxidant activities with the DPPH method $(51.1 \pm 5.5 \%)$ and greater content of total phenols (Yumrutaş \& al. 2009). Moreover, another study about the antioxidant activity of $A$. tuncelianum showed that aqueous and EtOH extracts (Ağbaş \& al. 2013) and $\mathrm{MeOH}$ extract (Şehitoğlu \& al. 2018) of bulbs got a significant effect. Other research also found a substantial correlation between antioxidant capacity and total phenolic content (Sytar \& al. 2015; Granato \& al. 2018) as well. 
Previous investigations indicated that the major constituents of essential oils of $A$. tuncelianum bulbs were diallyl tri- sulfides (30.90\%) and diallyl disulfide (28.30\%) (Takim \& al. 2016); diallyl disulfide (in green and red garlic was $67.33 \%$ and $72.52 \%$, respectively) (Kiralan \& al. 2013).

Nowadays it is known that diallyl disulfide derivatives are chemical agents that modulate various facets of $\mathrm{AD}$ (Manral \& al. 2015). Also, previous studies showed that some Allium species such as A. sativum and A. tuberosum Rottler ex Spreng. had significant effects on AD (Chauhan 2003; Kim \& al. 2007; Ray \& al. 2011).

$\mathrm{AD}$ is a neurodegenerative disease induced by oxidative stress with a further cholinergic lack in the brain. Particularly, AD is characterised by a reduction in the sum of acetylcholine delivered from cholinergic synapses. A therapy methodology has been stimulated to enhance or maintain the proportion of acetylcholine through inhibiting acetylcholinesterase (Dickson 1997). Essential oils are a miscellaneous family of low molecular weight organic compounds with circumstantial biological activity. Compounds that act as cholinesterase inhibitors still are the only pharmacological therapeutics for AD. Many in vitro examinations showed that some components, in essential oils, may have cholinesterase inhibitory activity (Karakaya \& al. 2019).

This paper showed that the EtOAc fraction of A. tuncelianum has cholinesterase inhibitory and antioxidant effects. The uses of antioxidants may be beneficial for $\mathrm{AD}$ healing (Gibson \& Huang 2005). To the literature surveys, this is the initial exploration of cholinesterase inhibitory activity of extracts, fractions and essential oil from A. tuncelianum.

Especially, EtOAc fraction of A. tuncelianum bulbs displayed a substantial cholinesterase inhibitory and antioxidant potentials. The studied essential oils, extracts and fractions exhibited radical scavenging capacity (RSC), which were detected to be in correlation to the content of phenolic compounds. The essential oil has been characterized by the presence of diallyl disulfide which was determined to have inhibition towards both cholinesterase inhibitory activities. This paper displays that the EtOAc fraction of $A$. tuncelianum could be a novel potency source of native antioxidant and anticholinesterase components.

\section{ACKNOWLEDGEMENTS}

This paper was supported by the Research Fund of Ataturk University (FHD-2019-7227).

\section{REFERENCES}

Ağbaş B., Karakuş D., Adigüzel R., Keser S. \& Demir E. 2013. Comparison of Total Antioxidant Properties and Dry Matter Content of Tunceli Garlic (Allium tuncelianum) and Normal Garlic (Allium sativum). Bilim ve Gençlik Dergisi 2: 50-62.

APGIII 2009. An update of the Angiosperm Phylogeny Group classification for the orders and the families of the flowering plants. Botanical journal of the Linnean Society 161: 105-121. https://doi.org/ 10.1111/j.1095-8339.2009.00996.x
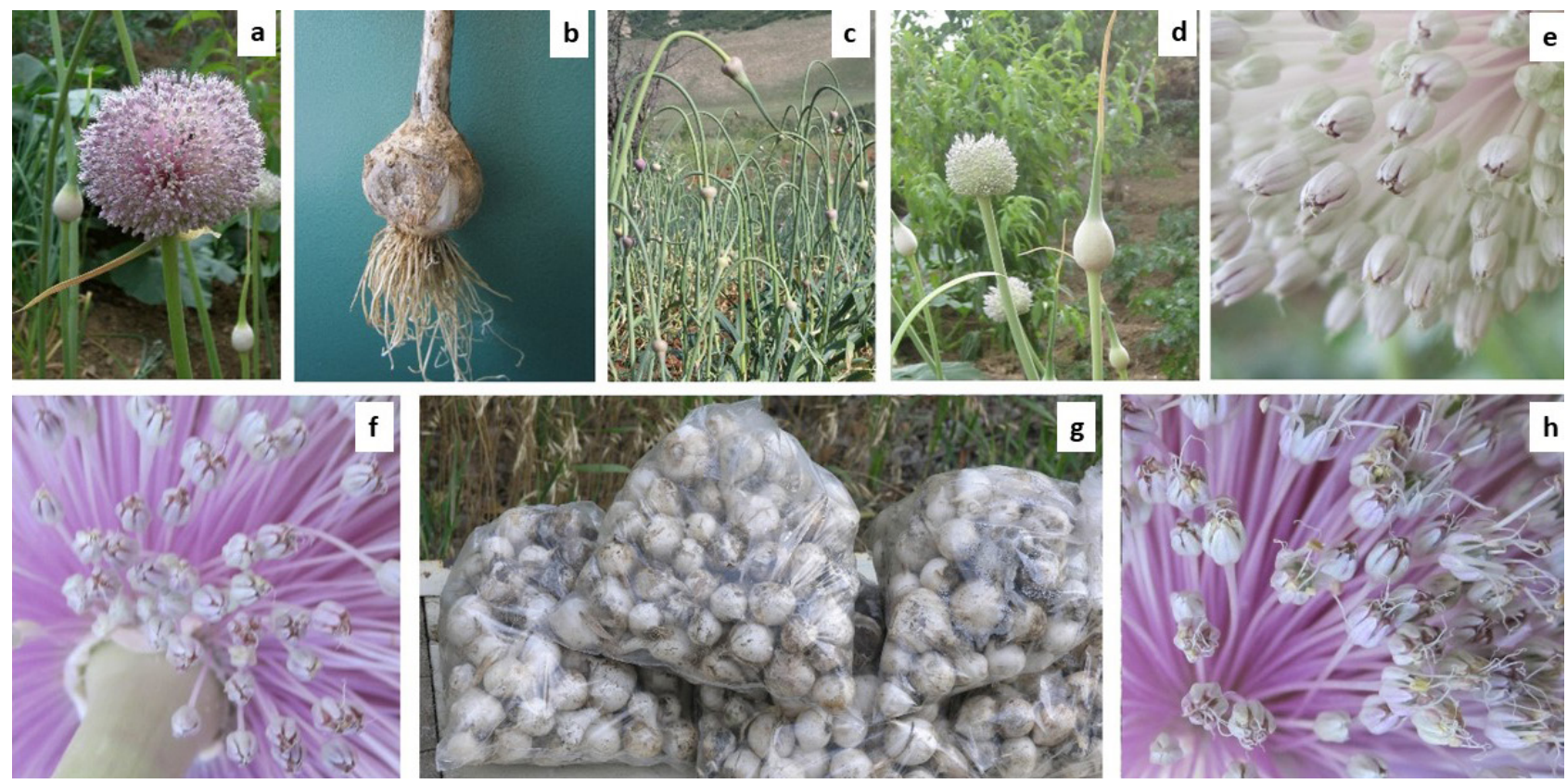

Fig. 2. Allium tuncelianum (Kollmann) Özhatay, B.Mathew \& Şiraneci: a, e, f, h, anthesis; b, bulb; c, d, early stages of the anthesis; g, bulbs at a local market. [Photos: a, b, d-f, h, Gülnur Ekşi; c, g, Mehmet Koyuncu]. 
Chand R.N., Gopalan R.D. \& Christi K. 2018. Evaluation of antioxidant properties in thirteen Fijian medicinal plants used in Alzheimer's disease and related illness. Free Radicals and Antioxidants 8 (1): 11-17.

Chauhan N.B. 2003. Anti-Amyloidogenic effect of Allium sativum in Alzheimer's transgenic model Tg2576. Journal of Herbal Pharmacotherapy 3: 95-107. https://doi.org/10.1080/J157v03n01 05

Dickson D.W. 1997. Neuropathological diagnosis of Alzheimer's disease: A perspective from longitudinal clinicopathological studies. Neurobiology of Aging 18: 21-26. https://doi.org/10.1016/S0197-4580(97)00065-1

Duman H., Ekşi G. \& Özbek F. 2017. Two new species of Allium L. sect. Allium (Amaryllidaceae) from Turkey. Plant Systematics and Evolution 303: 1271-1291. https://doi.org/10.1007/s00606-017-1437-4

Ekşi G., Koyuncu M. \& Özkan A.M.G. 2016. Allium ekimianum: a new species (Amaryllidaceae) from Turkey. PhytoKeys 62: 83-93. https://doi.org/10.3897/phytokeys.62.7796

Ellman G.L., Courtney K.D., Andresjr V. \& Featherstone R.M. 1961. A new and rapid colorimetric determination of acetylcholinesterase activity. Biochemical Pharmacology 7: 88-89. https://doi.org/10.1016/0006-2952(61)90145-9

Fritsch R.M. \& Friesen N. 2002. Evolution, Domestication and Taxonomy. CABI, Wallingford.

Gibson G.E. \& Huang H.M. 2005. Oxidative stress in Alzheimer's disease. Neurobiology of Aging 26: 575-578. https://doi.org/10.1016/j.neurobiolaging.2004.07.017

Granato D., Shahidi F., Wrolstad R., Kilmartin P., Melton L.D., Hidalgo F.J., Miyashita K., Camp J., Alasalvar C., Ismail A.B., Elmore S., Birch G.G., Charalampopoulos D., Astley S.B., Pegg R., Zhou P. \& Finglas P. 2018. Antioxidant activity, total phenolics and flavonoids contents: Should we ban in vitro screening methods? Food Chemistry 264: 471475. https://doi.org/10.1016/j.foodchem.2018.04.012

Karakaya S., Göger G., Kılıç C.S. \& Demirci B. 2016. Composition of volatile oil of the aerial parts, flowers and roots of Ferulago blancheana Post. (Apiaceae) growing in Turkey and determination of their antimicrobial activities by bioautography method. Turkish Journal Of Pharmaceutical Sciences 13: 173-180.

Karakaya S., Koca M., Kılıc C.S. \& Coskun M. 2018. Antioxidant and anticholinesterase activities of Ferulago syriaca Boiss. and F. isaurica Peşmen growing in Turkey. Medical Chemistry Research 27: 1843-1850. https://doi.org/10.1007/s00044-018-2196-7

Karakaya S., Koca M., Yılmaz S.V., Yıldırım K., Pınar N.M., Demirci B., Brestic M. \& Sytar O. 2019. Molecular docking studies of coumarins isolated from extracts and essential oils of Zosima absinthifolia Link as potential inhibitors for Alzheimer's Disease. Molecules 24 (4), E722: 1-18. https://doi.org/10.3390/molecules24040722

Kim M.J., Choi S., Kim H.K., Kim C.J., Hong B., Kim Y.J. \& Shin D.H. 2007. Activation effects of Allium Tuberosum Rottl. on choline acetyltransferase. Bioscience, Biotechnology, and Biochemistry 71: 226230. https://doi.org/10.1271/bbb.60314

Kiralan M., Rahimi A., Arslan N. \& Bayrak A. 2013. Volatiles in an endemic Allium species: Allium tuncelianum by headspace solid phase microextraction. TEOP 16: 417-420. https://doi.org/10.1080/0972060X.2013.813283

Kollmann F., Özhatay N. \& Koyuncu M. 1983. New Allium taxa from Turkey. Notes from the Royal Botanic Garden, Edinburgh 41 (2): 262.

López S., Bastida J., Viladomat F. \& Codina C. 2002. Acetylcholinesterase inhibitory activity of some Amaryllidaceae alkaloids and Narcissus extracts. Life Sciences 71: 2521-2529. https://doi.org/10.1016/S0024-3205(02)02034-9
Manral A., Saini V., Meena P. \& Tiwari M. 2015. Multifunctional novel diallyl disulfide (DADS) derivatives with b-amyloid-reducing, cholinergic, antioxidant and metal chelating properties for the treatment of Alzheimer's disease. Bioorganic \& Medicinal Chemistry 23: 63896403. https://doi.org/10.1016/j.bmc.2015.08.024

Mathew B. 1996. A review of Allium sect. Allium. Royal Botanic Gardens, Kew.

Mimica N.D., Bozin B., Sokovic M. \& Simin N. 2004. Antimicrobial and antioxidant activities of Melissa officinalis L. (Lamiaceae) essential oil. Journal of Agricultural and Food Chemistry 52: 2485-2489. https://doi.org/10.1021/jf030698a

Ng Y.P., Or T.C.T. \& Ip N.Y. 2015. Plant alkaloids as drug leads for Alzheimer's disease. Neurochemistry International 89: 260 e270. https://doi.org/10.1016/j.neuint.2015.07.018

Özhatay N. \& Mathew B. 1995. New taxa and notes on the genus Allium (Alliaceae) in Turkey and Arabia. Kew Bulletin 50 (4): 723-731. https://doi.org/10.2307/4110233

Özkan O., Gül S., Kart A., Çiçek B.A. \& Kılıç K. 2013. In vitro antimutagenicity of Allium tuncelianum ethanol extract against induction of chromosome aberration by mutagenic agent mitomycine C. Kafkas Üniversitesi Veteriner Fakültesi Dergisi 19: 259-262. https://doi.org/10.9775/kvfd.2012.7637

Ray B., Chauhan B.N. \& Lahiri K.D. 2011. The "Aged Garlic Extract" (AGE) and one of its active ingredients S-Allyl-LCysteine (SAC) as potential preventive and therapeutic agents for Alzheimer's disease (AD). Current Medicinal Chemistry 18: 3306-3313. https://doi.org/10.2174/092986711796504664

Resetár A., Freytag C., Kalydi F., Gonda S., M-Hamvas M., Ajtay K., Papp L. \& Máthé C. 2017. Production and antioxidant capacity of tissue cultures from four Amaryllidaceae species. Acta Societatis Botanicorum Poloniae 86: 3525. https://doi.org/10.5586/asbp.3525

Şehitoğlu M.H., Karakan F.Y., Kizilkaya B., Öztopuz R.Ö. \& Gülçin İ. 2018. Investigation of antioxidant properties and bioactive composition of Allium tuncelianum ((Kollman) Ozhatay, Matthew \& Siraneci) and Allium sativum L. Journal of the Institute of Science and Technology 8: 213-221. https://doi.org/10.21597/jist.427293

Sgarbossa A., Giacomazza D. \& Carlo M. 2015. Ferulic Acid: A Hope for Alzheimer's Disease Therapy from Plants. Nutrients 7: 5764-5782. https://doi.org/10.3390/nu7075246

Sytar O., Bruckova K., Hunkova E., Zivcak M., Kiessoun K. \& Brestic M. 2015. The application of muliplex flourimetric sensor for analysis flavonoids content in the medical herbs family Asteraceae, Lamiaceae, Rosaceae. Biological Research 48 (5): 2-9. https://doi.org/10.1186/0717-6287-48-5

Takim K., Kutlu T., İçen S., Demir N. 2016. Characterization of Tunceli mountain garlic essential oil component and determination effect on the antioxidant enzyme levels on rat renal tissue by dmba-induced. International Engineering, Science and Education Conference: 401-418.

Yerdelen K.O. \& Tosun E. 2015. Synthesis, docking and biological evaluation of oxamide and fumaramide analogs as potential AChE and BuChE inhibitors. Medical Chemistry Research 24: 588-602. https://doi.org/10.1007/s00044-014-1152-4

Yumrutaş Ö., Demir S., Saygideğer Ö. \& Doğan M. 2009. The in vitro antioxidant activity of Allium tuncelianum: An endemic. Journal of Applied Biological Sciences 3: 61-64. 